\title{
The Impact of Gender on Post-Operative Length of Stay after Lumbar Decompression Fusion Surgery Referable to Possible Comorbidity Factors
}

\author{
Hollis Floyd ${ }^{1 *}$, Mazen Sanoufa ${ }^{2}$, Joe Sam Robinson ${ }^{3}$ \\ ${ }^{1}$ Research assistant, masters in marriage and family therapy \\ ${ }^{2}$ Research fellow, doctor of medicine \\ ${ }^{3}$ Neurosurgeon, doctor of medicine
}

Received: August 16, 2016; Accepted: September 8, 2016; Published: September 16, 2016

*Corresponding author: Hollis Floyd, Masters in Marriage and Family Therapy, Research assistant at Georgia Neurosurgical Institute, United States.

Keywords: Costs; Comorbidities; Complications; Gender; Health Care Expenditure; Length of Stay; Lumbar Decompression and Fusion

\section{Introduction}

Proportionally more healthcare dollars are devoted to the care of females than their male counterparts (Lassman, Hartman, Washington, Andrews, \& Catlin, 2014); rightfully so, as females have a greater life expectancy and a special reproductive burden (Owens, 2008; Vaidya, Gautam, \& Karmakar, 2012). In neurosurgery, some controversy exists as to the influence of gender on prolonging hospital stay, particularly following operative intervention for spinal column difficulties (Table 1). To clarify such issues we conducted the following study.

\section{Methods}

A retrospective review of the clinical course of all patients that underwent elective lumbar spinal fusion procedures by five neurosurgeons between October 2010 and November 2013 at The Georgia Neurosurgical Institute was undertaken. Comorbidities, complications, and other relevant general variables were obtained. Comorbidities which included twenty four variables relating to preexisting diseases were collected from patients' past medical histories and their preoperative evaluation visit forms (Table 2). Complications were twelve secondary medical problems that developed during hospital stays that were not existent prior to the operation (Table 3). Other collected variables contained age, gender, race, Length of hospital Stay (LOS), Body Mass Index (BMI), and nine others (Table 4). LOS was measured from the day of procedure until the time of discharge (up to the first decimal of a day). As our patient's sample is relatively small in size, we chose to exclude those outliers who stayed more than 4 standard deviations above the mean length of stay ( $>25.3$ days). There were only 4 patients that fell into this category.

A simple t-test was used to study the mean gender difference in LOS. Then, the variables that showed more prevalence in one gender were identified using chi-squared analysis. Finally, each gender cohort was statistically studied separately in order to identify which variables lead to a prolonged LOS in each gender using multivariate linear regression analysis. SPSS-19 software was used to perform all statistics.

\section{Results}

A total number of 334 patients were assessed. The mean \pm SD

Table 1: Review of articles published in Pub Med since January 2013 about the impact of gender on length of stay in Spine Procedures.

\begin{tabular}{|l|l|l|l|}
\hline Paper & Year & $\begin{array}{l}\text { Study Sample } \\
\text { Underwent }\end{array}$ & Gender related result \\
\hline $\begin{array}{l}\text { Herren et } \\
\text { al.17 }\end{array}$ & 2014 & $\begin{array}{l}\text { Posterior lumbar } \\
\text { spine fusion } \\
\text { procedures }\end{array}$ & $\begin{array}{l}\text { Male gender was a factor } \\
\text { prolonged LOS }\end{array}$ \\
\hline $\begin{array}{l}\text { Schoenfeld et } \\
\text { al.18 }\end{array}$ & 2013 & Spine trauma & $\begin{array}{l}\text { Male gender was a } \\
\text { predictor for higher } \\
\text { mortality and higher } \\
\text { complication rate }\end{array}$ \\
\hline Alosh et al.19 & 2015 & $\begin{array}{l}\text { Anterior cervical } \\
\text { spine surgery }\end{array}$ & $\begin{array}{l}\text { Male gender was an } \\
\text { independent predictor of } \\
\text { hospital charges and LOS }\end{array}$ \\
\hline Kelly et al.20 & 2014 & $\begin{array}{l}\text { Surgical correction } \\
\text { of spondylolisthesis }\end{array}$ & $\begin{array}{l}\text { Female gender was a factor } \\
\text { prolonged LOS }\end{array}$ \\
\hline $\begin{array}{l}\text { Yoshihara et } \\
\text { al.21 }\end{array}$ & 2014 & $\begin{array}{l}\text { Surgical treatment } \\
\text { of thoracic disc } \\
\text { herniation }\end{array}$ & $\begin{array}{l}\text { Female gender was a risk } \\
\text { factor for mortality }\end{array}$ \\
\hline Sharma et & 2014 & $\begin{array}{l}\text { Spinal cord tumor } \\
\text { surgeries }\end{array}$ & $\begin{array}{l}\text { Female gender was an } \\
\text { independent predictor } \\
\text { of adverse discharge } \\
\text { disposition but not to } \\
\text { higher costs }\end{array}$ \\
\hline Wait et al.23 & 2013 & $\begin{array}{l}\text { Cervical or Lumbar } \\
\text { spinal fusions }\end{array}$ & $\begin{array}{l}\text { Gender did not show any } \\
\text { impact on LOS }\end{array}$ \\
\hline
\end{tabular}


length of stay was $5.68 \pm 4.9$ days. After taking out 4 patients who stayed for more than 25.3 days ( 4 SDs above the mean LOS), the mean was found to be $5.3 \pm 3.4$ days. The remaining 330 patients were divided into 190 females and 140 males (see tables 1, 2, and 3 for a detailed description). Females stayed for 1 day longer than males ( $\mathrm{F}=5.7 \pm 3.1, \mathrm{M}=4.7 \pm 3.7 ; \mathrm{P}=0.008)$.

A history of coronary artery disease was the only variable that showed more prevalence in the male cohort $(\mathrm{P}=0.041)$. However, variables that were more prevalent in the female cohort were postoperative anemia severity $(\mathrm{P}<0.001)$, vitamin $\mathrm{D}$ deficiency $(\mathrm{P}=0.014)$, diabetes mellitus $(\mathrm{P}=.05)$, hypothyroidism $(\mathrm{P}=0.005)$, anxiety disorders $(\mathrm{P}=0.002)$, major depressive disorder $(\mathrm{P}=0.001)$, obesity $(\mathrm{BMI}>30, \mathrm{P}=0.013)$, hypotension $(\mathrm{P}=0.029)$, severe postoperative respiratory problems $(\mathrm{P}=0.055)$, and postoperative psychiatric symptoms $(\mathrm{P}=0.045)$.

Variables that showed a significant impact on LOS in the male cohort were postoperative anemia $(\mathrm{P}=0.033)$, number of operated levels $(\mathrm{P}=0.053)$, developing postoperative infections $(\mathrm{P}=0.012)$, postoperative pulmonary embolism $(\mathrm{P}=0.008)$, and

Table 2: The Collected Co morbidities.

\begin{tabular}{|c|c|c|c|}
\hline & All patients & Males & Females \\
\hline Preoperative Anemia $(\mathrm{Y} / \mathrm{N})$ & $30.0 \%$ & $30.2 \%$ & $29.4 \%$ \\
\hline Myocardial Infarction & $3.7 \%$ & $4.3 \%$ & $3.2 \%$ \\
\hline $\begin{array}{l}\text { Coronary Artery Disease } \\
\text { (other than MI) }\end{array}$ & $11.0 \%$ & $15.0 \%$ & $7.9 \%$ \\
\hline Congestive Heart Failure & $1.5 \%$ & $1.4 \%$ & $1.6 \%$ \\
\hline Arrhythmias & $4.8 \%$ & $5.7 \%$ & $4.2 \%$ \\
\hline Hypertension & $66.1 \%$ & $63.6 \%$ & $67.9 \%$ \\
\hline $\begin{array}{l}\text { Respiratory Disorders (other } \\
\text { than sleep related) }\end{array}$ & $26.2 \%$ & $23.0 \%$ & $28.6 \%$ \\
\hline $\begin{array}{l}\text { Chronic Obstructive } \\
\text { Pulmonary Disease }\end{array}$ & $11.6 \%$ & $12.2 \%$ & $11.1 \%$ \\
\hline Sleep Apnea & $10.4 \%$ & $12.9 \%$ & $8.5 \%$ \\
\hline Chronic Constipation & $14.2 \%$ & $12.9 \%$ & $15.3 \%$ \\
\hline Peptic Ulcer Disease & $2.7 \%$ & $2.1 \%$ & $3.2 \%$ \\
\hline Renal Failure & $2.1 \%$ & $1.4 \%$ & $2.6 \%$ \\
\hline Diabetes Mellitus & $30.0 \%$ & $24.3 \%$ & $34.2 \%$ \\
\hline Hypothyroidism & $18.6 \%$ & $11.5 \%$ & $23.8 \%$ \\
\hline Stroke & $5.5 \%$ & $4.3 \%$ & $6.3 \%$ \\
\hline Transient Ischemic Attach & $1.8 \%$ & $0.7 \%$ & $2.6 \%$ \\
\hline Seizure & $2.1 \%$ & $0.7 \%$ & $3.2 \%$ \\
\hline Neuromuscular Disorders & $1.8 \%$ & $1.4 \%$ & $2.1 \%$ \\
\hline Memory Loss & $5.5 \%$ & $3.6 \%$ & $6.8 \%$ \\
\hline Anxiety Disorders & $20 \%$ & $12.1 \%$ & $25.8 \%$ \\
\hline Major Depression & $26.1 \%$ & $16.4 \%$ & $33.2 \%$ \\
\hline Arthritis & $58.8 \%$ & $61.4 \%$ & $56.8 \%$ \\
\hline Obesity (BMI $\geq 30)$ & $57.1 \%$ & $49.3 \%$ & $63.0 \%$ \\
\hline Morbid Obesity (BMI $\geq 40)$ & $10.6 \%$ & $10.0 \%$ & $11.1 \%$ \\
\hline Total Comorbidities & 5.8 & 5.4 & 6.1 \\
\hline
\end{tabular}

\begin{tabular}{|c|c|c|c|c|}
\hline & & $\begin{array}{l}\text { All } \\
\text { patients }\end{array}$ & Males & Females \\
\hline \multirow{4}{*}{$\begin{array}{l}\text { Postoperative Anemia } \\
\text { Severity }\end{array}$} & $\begin{array}{l}\text { No anemia } \\
\text { ( } \geq 12 \text { in } \mathrm{f} \text {. / } \\
\geq 13.5 \text { in } \mathrm{m} \text {.) }\end{array}$ & $4.6 \%$ & $5 \%$ & $4.3 \%$ \\
\hline & $\begin{array}{l}\text { Mild Anemia } \\
(<12 \text { in } \mathrm{f} . / \\
<13.5 \text { in } \mathrm{m} \text {. to } \\
\geq 10)\end{array}$ & $32.3 \%$ & $51.8 \%$ & $17.7 \%$ \\
\hline & $\begin{array}{l}\text { Moderate }(<10 \\
\text { to } \geq 8)\end{array}$ & $39.1 \%$ & $32.4 \%$ & $44.1 \%$ \\
\hline & Severe $(<8)$ & $24 \%$ & $10.8 \%$ & $33.9 \%$ \\
\hline Dural Tear/CSF Leak & & $3.4 \%$ & $1.4 \%$ & $4.7 \%$ \\
\hline Fever & & $24.7 \%$ & $20.3 \%$ & $22.6 \%$ \\
\hline Infections (total) & & $12.2 \%$ & $9.4 \%$ & $14.2 \%$ \\
\hline Urinary Tract Infection & & $3.7 \%$ & $2.2 \%$ & $4.7 \%$ \\
\hline Wound Infection & & $2.4 \%$ & $2.2 \%$ & $2.6 \%$ \\
\hline Respiratory Complaints & & $7.0 \%$ & $5.8 \%$ & $7.9 \%$ \\
\hline Pulmonary Embolism & & $1.2 \%$ & $2.2 \%$ & $0.5 \%$ \\
\hline Urinary Retention & & $2.4 \%$ & $1.4 \%$ & $3.2 \%$ \\
\hline $\begin{array}{l}\text { Postoperative } \\
\text { Psychiatric Symptoms } \\
\text { (e.g. hallucination, } \\
\text { delirium) }\end{array}$ & & $3.0 \%$ & $0.7 \%$ & $4.7 \%$ \\
\hline Constipation & & $12.5 \%$ & $9.4 \%$ & $14.7 \%$ \\
\hline $\begin{array}{l}\text { Total Number of } \\
\text { Complication }\end{array}$ & & 2.2 & 2.1 & 2.2 \\
\hline
\end{tabular}

postoperative glucose intolerance $(\mathrm{P}=0.045)$. However, variables that showed a significant impact on LOS in the female cohort were postoperative anemia severity $(\mathrm{P}=0.029)$, developing postoperative urinary retention $(\mathrm{P}=0.006)$, postoperative respiratory complications $(\mathrm{P}=0.006)$, spinal dural tear $(\mathrm{P}<0.0001)$, and neuromuscular disorders $(\mathrm{P}=0.005)$.

\section{Discussion}

Our study demonstrated that females have more comorbidities than males which might be referable to the different hormonal structures between genders. Our study also recognized that the variables that influence LOS in each gender cohort are different. However, age did not show an independent influence on LOS in either of the genders, despite females being significantly older than males in our study. Recognizing this age disparity, statistical adjustments were accordingly instituted. Following such statistical adjustment, age by itself did change gender's impact on LOS.

Another variable that should be discussed is rehabilitation status. Ireland, Kelly, and Cumming (2015) stated that "referral to hospital-based rehabilitation effectively doubles the total LOS," suggesting that anyone who is subject to rehabilitation after their acute hospital stay will have a longer LOS. This suggests that a patient's post-operative rehabilitation status should be taken into account when determining their LOS. It may be that patients 


\begin{tabular}{|c|c|c|c|c|}
\hline & & All patients & Males & Females \\
\hline $\begin{array}{l}\text { Length of } \\
\text { Hospital Stay } \\
\text { (Days) }\end{array}$ & & 5.3 & $4.7 \pm 3.7$ & $5.7 \pm 3.1$ \\
\hline Gender & & & $140(42 \%)$ & $190(57 \%)$ \\
\hline \multirow[b]{2}{*}{ Age } & & 58.0 & $56.1 \pm 13$ & $58.6 \pm 9.7$ \\
\hline & $\begin{array}{l}>60 \text { years } \\
\text { old }\end{array}$ & $48.8 \%$ & $46.4 \%$ & $50.5 \%$ \\
\hline \multirow[b]{2}{*}{ Race } & Caucasians & & $76.4 \%$ & $64.2 \%$ \\
\hline & $\begin{array}{l}\text { African } \\
\text { American }\end{array}$ & & $20.7 \%$ & $34.7 \%$ \\
\hline \multirow{5}{*}{$\begin{array}{l}\text { Type of } \\
\text { Insurance }\end{array}$} & Medicare & & $56.4 \%$ & $55.8 \%$ \\
\hline & Medicaid & & $5.7 \%$ & $7.9 \%$ \\
\hline & \begin{tabular}{|l|} 
Private \\
Insurance
\end{tabular} & & $26.4 \%$ & $24.7 \%$ \\
\hline & Uninsured & & $5.0 \%$ & $4.7 \%$ \\
\hline & Other & & $5.0 \%$ & $6.8 \%$ \\
\hline \multirow{4}{*}{$\begin{array}{l}\text { Number of } \\
\text { Operated } \\
\text { Levels }\end{array}$} & 1 & & $47.1 \%$ & $42.1 \%$ \\
\hline & 2 & & $27.1 \%$ & $32.6 \%$ \\
\hline & 3 & & $16.4 \%$ & $15.8 \%$ \\
\hline & $>3$ & & $9.3 \%$ & $9.5 \%$ \\
\hline $\begin{array}{l}\text { Body Mass } \\
\text { Index (BMI in } \\
\mathrm{kg} / \mathrm{m} 2 \text { ) }\end{array}$ & & 31.1 & 30.3 & 31.6 \\
\hline $\begin{array}{l}\text { Anti-Platelet } \\
\text { use }\end{array}$ & & $26.4 \%$ & $28.3 \%$ & $25.0 \%$ \\
\hline \begin{tabular}{|l} 
Drain \\
insertion
\end{tabular} & & $64.3 \%$ & $66.7 \%$ & $62.6 \%$ \\
\hline Cell Saver Use & & $72.9 \%$ & $68.8 \%$ & $75.8 \%$ \\
\hline \begin{tabular}{|l} 
The Need \\
for Blood \\
Transfusion
\end{tabular} & & $10.5 \%$ & $7.3 \%$ & $12.8 \%$ \\
\hline $\begin{array}{l}\text { Preoperative } \\
\text { Hemoglobin } \\
\text { Level }\end{array}$ & & 13.4 & 14.3 & 12.7 \\
\hline $\begin{array}{l}\text { Postoperative } \\
\text { Hemoglobin } \\
\text { Level }\end{array}$ & & 9.5 & 10.3 & 8.9 \\
\hline \multirow{2}{*}{$\begin{array}{l}\text { Vitamin D } \\
\text { (ng/mL) }\end{array}$} & & 27.3 & 28.9 & 26.3 \\
\hline & $\begin{array}{l}\text { Vitamin D } \\
<20\end{array}$ & $29.1 \%$ & $19.5 \%$ & $35.5 \%$ \\
\hline
\end{tabular}

otherwise able to depart a tertiary care facility are shunted into a rehabilitation facility because of inadequate domestic support apparatus. Secondly, in some circumstances, discharge arrangements may have been expedited, preoperatively, so that in some cases those patients going to rehabilitation facilities will leave the hospital sooner than a cohort returning to a home environment.

\section{Implications for Practice and/or Policy}

A past history of anxiety disorders and developing postoperative psychiatric symptoms occurred more frequently in females than in males; issues which have been suggested to cause a prolonged hospital LOS (Stundner, et al., 2013; Zatzick, et al., 2000). Moreover, studies consistently assert that chronic pain states are more prevalent in patients with anxiety disorders (Dersh, Polatin, Gatchel, 2000; Lachlan, McWilliams, Cox, 2003; Demyttenaere, Bruffaerts, Lee, 2007) and depressive disorders (Banks, Kerns, 1996; Dersh, Polatin, Gatchel, 2000; Von Korff, et al., 2005; Currie and Wang, 2004). Furthermore, women tend to have more severe pain scores, and perform more poorly on tests of cognitive function postoperatively than men (Heyer, et al., 2000). Also, it was suggested by Korovessis, Pepantis, Papazisis, and Iliopoulos (2010) that males show significantly better improvement in their lower back pain scores than their female counterparts following spine surgery. The psychological, pain, and cognitive burdens that females must face after surgery suggest that females are innately inclined to poorer postoperative outcomes and, thus, an elongated LOS.

In our study cohort females were afflicted with more comorbidites than were males possibly referable to the differing hormonal profile of females that could provide further insight as to why female's have a longer LOS than men. Studies consistently mentioned that estrogen modulates pain sensation via its $\alpha$ and $\beta$ receptors that spread throughout the central and peripheral nervous systems (Alstergren, Ernberg, Kvarnström, Kopp, 1998; Nomura, et al., 2005; McEwen and Alves, 1999), including the dorsal root ganglia (Papka, et al., 2001), as well as throughout inflammatory cells like monocytes (Phiel, Henderson, Adelman, Elloso, Lett, 2005). The study performed by Craft et al. implicated that estrogen was a stimulant of nociceptive afferents in the peripheral nervous system via different mechanisms (Craft, 2007). Female's inclination to have a higher sensitivity to pain, and their increased tendency to psychiatric distress both could contribute to their elongated LOS.

\section{Conclusion}

Understanding the differences in gender for different operative interventions and paying special attention to gender dissimilarities might be useful to decrease postoperative stay and, thus, diminish healthcare expenditure.

We suggest additional inquiry into the impact of comorbidities and complications with particular reference as to why certain comorbidities and complications contribute to prolonging female LOS and not male.

\section{References}

1. Alstergren P, Ernberg M, Kvarnström M, Kopp S. Interleukin-1beta in synovial fluid from the arthritic temporomandibular joint and its relation to pain, mobility, and anterior open bite. J Oral Maxillofac Surg. 1998;56(9):1059-1066. DOI:10.1016/S0278-2391(98)902567

2. By Banks, Sara M, Kerns, Robert D. Explaining high rates of depression in chronic pain: A diathesis-stress frame work. Psychological Bulletin.1996;119(1);95-110. DOI: 10.1037/0033-2909.119.1.95.

3. Craft RM. Modulation of pain by estrogens. Pain. 2007;132:S3-S12.

4. Currie SR, Wang JL. Chronic back pain and major depression in the general Canadian population. Pain. 2004;107(1-2):54-60. DOI:10.1016/j.pain.2003.09.015.

5. Demyttenaere $K$, Bruffaerts $R$, Lee $S$, Posada-Villa J, Coves $v$, Mneimneh Z, et al. Mental disorders among persons with chronic back or neck pain: Results from the World Mental Health Surveys. Pain. 2007;129(3):332-342. DOI: 10.1016/j.pain.2007.01.022. 
6. Dersh J, Polatin PB, Gatchel RJ. Chronic pain and psychopathology: Research findings and theoretical considerations. Psychosom Med. 2002;64(5):773-786. DOI:10.1097/01.PSY.0000024232.11538.54.

7. Heyer EJ, Sharma R, Winfree CJ, McCormick PA, Connolly ES Jr, Riedel CJ, et al. Severe pain confounds neuropsychological test performance. J Clin Exp Neuropsychol. 2000;22(5):633-639.

8. Ireland AW, Kelly PJ, Cumming RG. Total hospital stay for hip fracture Measuring the variations due to pre-fracture residence, rehabilitation complications and comorbidities. BMC Health Serv Res. 2015;15(1):774-788. DOI:10.1186/s12913-015-0697-3.

9. Korovessis P, Repantis T, Papazisis Z, Iliopoulos P. Effect of sagittal spinal balance, levels of posterior instrumentation, and length of follow-up on low back pain in patients undergoing posterior decompression and instrumented fusion for degenerative lumbar spine disease: A multifactorial analysis. Spine. 2010;35(8):898-905. DOI:10.1097/BRS.0b013e3181d51e84.

10. Lachlan A, McWilliams BJ, Cox MW. Mood and anxiety disorders associated with chronic pain: An examination in a nationally representative sample. Pain

11.2003;106(1-2):127-133. doi.org/10.1016/S0304-3959(03)00301-4.

12. Lassman D, Hartman M, Washington B, Andrews K, Catlin A, US health spending trends by age and gender: Selected years 200210. Health aff (Millwood). 2014;33(5):815-822. DOI:10.1377/ hlthaff.2013.1224.

13. McEwen BS, Alves SE. Estrogen actions in the central nervous system. Endocr Rev. 1999;20(3):279-307. DOI:10.1210/edrv.20.3.0365.

14. Nomura M, Akama KT, Alves SE, Korach KS, Gustafsson JA, Pfaff DW et al. (2005). Differential distribution of estrogen receptor (ER)-alpha and ER-beta in the midbrain raphe nuclei and periaqueductal gray in male mouse: Predominant role of ER-beta in midbrain serotonergic systems. Neuroscience. 2005;130(2):445-456. DOI:10.1016/j. neuroscience.2004.09.028

15. Owens G. Gender differences in health care expenditures, resource utilization, and quality of care. J Manag Care Pharm. 2008;14(3): suppl, S2-S6.

16. Papka RE, Storey-Workley M, Shughrue PJ, Collins JJ, Saunders PT, USip S. et al. Estrogen receptor-alpha and beta- immunore activity and mRNA in neurons of sensory and autonomic ganglia and spinal cord. Cell Tissue Res . 2001;304(2):193-214. doi:10.1007/ s004410100363.

17. Phiel KL, Henderson RA, Adelman SJ, Elloso MM, Lett I. Differential estrogen receptor gene expression in human peripheral blood. Immunol Lett. 2015;97(1):107-113. DOI:10.1016/j. imlet.2004.10.007.
18. Stundner O, Kirksey M, Chiu YL, Mazumdar M, Poultsides L, Garner p. et al. Demographics and perioperative outcome in patients with depression and anxiety undergoing total joint arthroplasty: A population based study. Psychosomatics. 2013;54(2):14957. doi:10.1016/j.psym.2012.08.009.

19.Vaidya V, Gautam P, Karmakar M. Gender differences in utilization of preventive care services in the United States. J Womens Health. 2012;21(2):140-145. Doi:10.1089/jwh.2011.2876.

20. Von Orff M, Crane P, Lane M, Brandenburg N, Simon G, Kessler R. et al. Chronic spinal pain and physical-mental co morbidity in the United States: Results from the national co morbidity survey replication. Pain. 2005;113(3):331-339. DOI: 10.1016/j.pain.2004.11.010.

21.Zatzick DF, Kang SM, Kim SY, Leigh P, Kravitz R, Drake C, et al. Patients with recognized psychiatric disorders in trauma surgery: Incidence, inpatient length of stay, and cost. J Trauma. 200;49(3):487495.

22. Alosh H, Li D, Riley LH III, Skolasky RL. Health care burden of anterior cervical spine surgery: National trends in hospital charges and length of stay. 2000-2009. J Spinal Disord Tech. 2015;28(1):5-11. DOI:10.1097/BSD.0000000000000001.

23. Herren C, Aghayev E, Kaulhausen T, Roeder C, Meyer F, Siege J, Soothe R. Influencing factors on the length of stay in lumbar spine surgery: Analysis of the German spine registry. Orthapade. 2014;43(12):1043-1051. DOI:10.1007/s00132-014-3033-4.Kelly AM, Batke JN, Dea N, Hartig DP, Fisher CG, Street JT. Prospective analysis of adverse events in surgical treatment of degenerative spondylolisthesis. Spine J. 2014;14(12):2910-2910. DOI:10.1016/j. spinee.2014.04.016.

24. Schoenfeld AJ, Belmont PJ Jr, See AA, Bader JO, Bono CM. Patient demographics, insurance status, race, and ethnicity as predictors of morbidity and mortality after spine trauma: A study using the National Trauma Data Bank. Spine J. 2013;13(2):1766-1773. DOI:10.1016/j. spinee.2013.03.024.

25. Sharma M, Sonig A, Ambekar S, Nanda A. Discharge dispositions, complications, and costs of hospitalization in spinal cord tumor surgery: Analysis of data from the United States nationwide inpatient sample.2003-2010. J Neurosurgeon Spine. 2014;20(2):125-141. DOI:10.3171/2013.9.SPINE13274.

26. Waits KD, Walid SM, Robinson JS. Preoperative pain intensity and chronicity and postoperative analgesia markers of length of stay in patients undergoing spinal fusion. Perm J. 2013;17(2):4143. DOI:10.7812/TPP/12-078.

27. Yoshihara H,Yoneoka D. Comparison of in-hospital morbidity and mortality rates between anterior and non-anterior approach procedures for thoracic disc hernia ion. Spine. 2014;39(12):728-733. DOI:10.1097/BRS.0000000000000322. 